\title{
I WATCH MOVIES: A LOOK INTO HOW INFORMAL L2 LEARNERS ACQUIRE A NEW LANGUAGE
}

\author{
Sya'baningrum Prihhartini ${ }^{1}$ and Fahmi Hasan $^{2}$ \\ Universitas Islam '45', Bekasi, syabaningrum@englit45bekasi.org \\ Universitas Islam '45², Bekasi, fauzyh46@ gmail.com
}

\begin{abstract}
The present study sought to investigate how much independent second language learners acquire new language through movies. With the growing of Over-The Top (OTT) media services such as Netflix and Viu, which provide movies in many languages and from various nations, the possibility for public in general to watch any movies in any language is limitless, hence exposing them to acquire a new language. Two surveys, one about English and another about Korean acquisition, were conducted via Google Form and distributed via social media to examine how much informal L2 learners retrieve their stored input acquired from the movie viewing. Data collected were analyzed using mixed method data analysis. The result show that Korea movie viewers could recall more words than the English movie viewers. Korean movie viewers also seem to perform more on productive retrieval as they use the words they get from movies to communicate with their community. English movie viewers, on the other hand, seem to perform more on receptive retrieval as they can understand the story of the movies without needing subtitle. The findings suggest that watching movies greatly expose viewers to language input, which can be a great source of output when interacting within the movie-based community that they belong to.
\end{abstract}

Keywords: movies, informal L2 learner, incidental vocabulary acquisition, second language input

\section{INTRODUCTION}

Nowadays, it is very common for us to encounter a lot of Korean words, like "Annyeong haseyo", "Daebak", "Oppa", Hyung", "Saranghaeyo" used by Indonesian netizens (an active participant in the online community of the Internet) in their social media accounts like Instagram or Twitter. Since the emergence of "Korean Wave" or "Hallyu" at the end of 1990s (Effendi, Malihah, \& Nurbayani, 2016; Jin \& Yoon, 2017; Putri \& Reese, 2018; Ramadhani \& Linadi, 2012), in forms of Korean Drama and K-Pop, Indonesian people have been so intrigued by Korean culture and product (Putri \& Reese, 2018), in particular the language (Effendi et al., 2016; Ramadhani \& Linadi, 2012). This interest on Korean language led to a significant increase of Korean language book sales in Indonesia by $40 \%$ in 2005 (Effendi et al., 2016). It is, therefore, intriguing to see how such a cultural impact (Rahmiati, 2012) was brought by a phenomenon of drama watching.

Movies can be entertaining (Carraher, 2017), motivational (Goctu, 2017; Ismaili, 2013; Kabooha, 2016; King, 2002), invaluable teaching recourses (King, 2002), stimulating (Seferoğlu, 2008), and powerful instructional tool (Kabooha, 2016). Because of that, movies can be a platform where incidental language acquisition happens, particularly to informal language learners. The term "informal 
L2 learner" used in this study refers to viewers who watch foreign movies and incidentally acquire a new language without getting formal language instruction. These learners get exposed to a huge amount of input of the target language in their everyday life and are able to "pick up" words of the target language and use them to communicate with their peers. This condition is called naturalistic L2 learning or informal L2 learning (Saville-Troike, 2006, p.192) which leads to acquisition, or in Krashen's term, “picking-up" a language (2009, p. 10).

The present study seeks to reveal what incidental second language learners, in particular Korean and English movie viewers, gain while doing one of the activities they enjoy immensely: watching movies.

\section{LITERATURE REVIEW}

Nation (2001) lays out 3 conditions that help learners remember words: 1) noticing, 2) retrieval, and 3) creative/generative use. Noticing (see Robbinson, Mackey, Gass, \& Schmidt, 2012; Schmidt, 2001, 2010 for further discussion) happens when learner notices the word and becomes aware of it as a useful language item (Nation, 2001). It can also happen when learners search for the meaning of the word in a dictionary or guess the word from the context. Nation states that there are several factors, including salience of the word ( see Leeman, 2003; Ziegler, 2018) that can affect noticing. Words that are more salient, for example, expressed in high-pitched voice, are said more likely to be noticed and acquired over non-salient forms (Leeman, 2003). Another condition that helps learners remember words is retrieval. When learner, after noticing and understanding a word in the textual input, subsequently retrieves the word during the task, then the memory of word will be strengthened (Nation, 2001). Learner might perform either receptive retrieval or productive retrieval. Receptive retrieval happens when the learner has to retrieve the word during listening or reading, and productive retrieval happens when learner has to retrieve its spoken or written form during speaking or writing (ibid). The last condition is creative or generative use. It happens when th learner encounters or uses a word in a way that differs from the previous meeting with the word (ibid).

When it comes to incidental vocabulary learning, Nation emphasizes the importance of repetition (2001). He stresses that learner needs to meet the recently met word again before the memory of the previous meeting fades. When a long period has passed between the previous meeting and the recent one, then the present meeting is considered a first encounter with the word, not a repetition (ibid).

Earlier studies of incidental vocabulary learning used extensive reading (Pigada \& Schmitt, 2006) or audio (van Zeeland \& Schmitt, 2013; Vidal, 2011) as input sources. In recent years, researchers started to notice the possibility of using audio-visual media, either in forms of short clips or full-length movies, as medium that facilitate vocabulary learning for a number of reasons. Movies can be entertaining (Carraher, 2017), motivational (Goctu, 2017; Ismaili, 2013; Kabooha, 2016; King, 2002), invaluable teaching recourses (King, 2002), stimulating (Seferoğlu, 2008), and powerful instructional tool (Kabooha, 2016) that can aid students acquire "comprehensible input" (Krashen, 1981, 1985, 2004, 2009; Rodrigo, Krashen, \& Gribbons, 2004). 
A number of studies have investigated the effect of movie viewing on incidental vocabulary learning (Ashcroft, Garner, \& Hadingham, 2018; Dzulfahmi \& Nikmah, 2019; Mardani \& Najmabadi, 2016; Montero Perez, Peters, \& Desmet, 2018; Peters \& Webb, 2018). Ashcroft et.al (2018) investigated the effect of watching a single movie in English on the ability of Japanese students to recall a selection of words taken from the movie script. The study involved 187 native Japanese, who were put in experimental and control group. Pre-test and post-test were administered before and after the treatment to see if there was a good gain resulted from the treatment. The study saw a significant increase in the students' ability to recall words directly after watching the movie. The study also found that audio-visual input helped provide a great boost to the students' rate of vocabulary acquisition.

Another study by Peters \& Webb (2018) examined the effect of viewing a single full-length TV program on incidental vocabulary acquisition. The study investigated 3 word-related variables, namely frequency of occurrence, cognateness, and word relevance, as well as prior vocabulary knowledge on Dutchspeaking EFL learners. The result indicated that viewing TV resulted in incidental vocabulary learning at the level of meaning recall and meaning recognition. They also found that learning was affected by frequency of occurence, prior knowledge, and cognateness.

Most studies related to incidental vocabulary learning examined the effect using short clips or an-hour length video (Ashcroft et al., 2018; Montero Perez et al., 2018) and some other utilized a full-length video (Dzulfahmi \& Nikmah, 2019; Mardani \& Najmabadi, 2016; Peters \& Webb, 2018). Currently there is no study that investigates the effect of years of movie viewing on incidental vocabulary learning. The present study fills that gap.

\section{METHOD}

The present study conducted two identical surveys, those were: 1) Korean input through Korean movies/drama, and 2) English input through English movies/series. The surveys were put in Google Forms and distributed through social media. The list of questions can be found in Appendix. The collected survey was analyzed using mixed method data analysis. The open-ended questions were analyzed qualitatively and some of the questions were analyzed quantitatively. The following research question leads study to be more focus, namely, 'how much do informal L2 learners retrieve their stored input acquired from the movie viewing?' 


\section{FINDINGS AND DISCUSSIONS}

There were 83 respondents who filled out the survey for Korean survey, and there were 20 respondents who filled out the English survey. Among the Korean survey respondents, a jarring gender unbalance were present with $95 \%$ female and $5 \%$ male. The English survey had a slightly better gender balance, with $66 \%$ female and $34 \%$ male. Both survey respondents shared similarity in regards to their age which ranged from 20 s to 40 s.

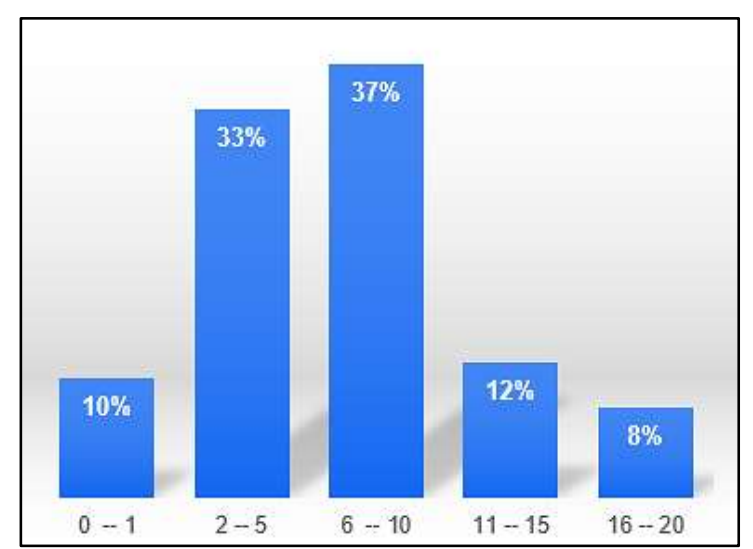

a

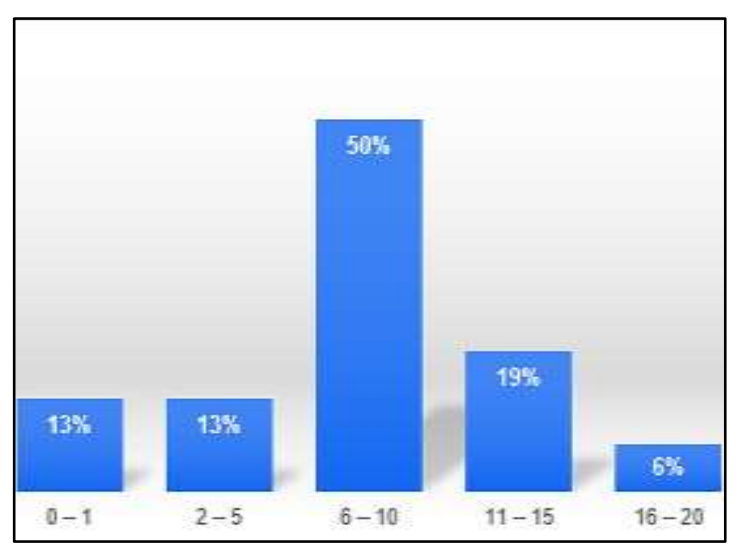

b

Figure 1. (a) Years of exposure towards Korean movies/drama; (b) Years of exposure towards English movies/series

From the two figures projecting years of exposure towards foreign movies, both Korean movie viewers and English movie viewers's largest group belong to those with $6-10$ years of exposure. Korean movie viewers with 2 to 5 years of experience comes as the second largest group with 33\%, while the second largest group for English movie viewers belongs to those with higher years of experience (11 to 15 ) at $19 \%$. Another difference is that Korean movie watchers has more viewers with highest years of experience of movie watching (20 years) at $8 \%$ while English' group with longest experience comes at $6 \%$.
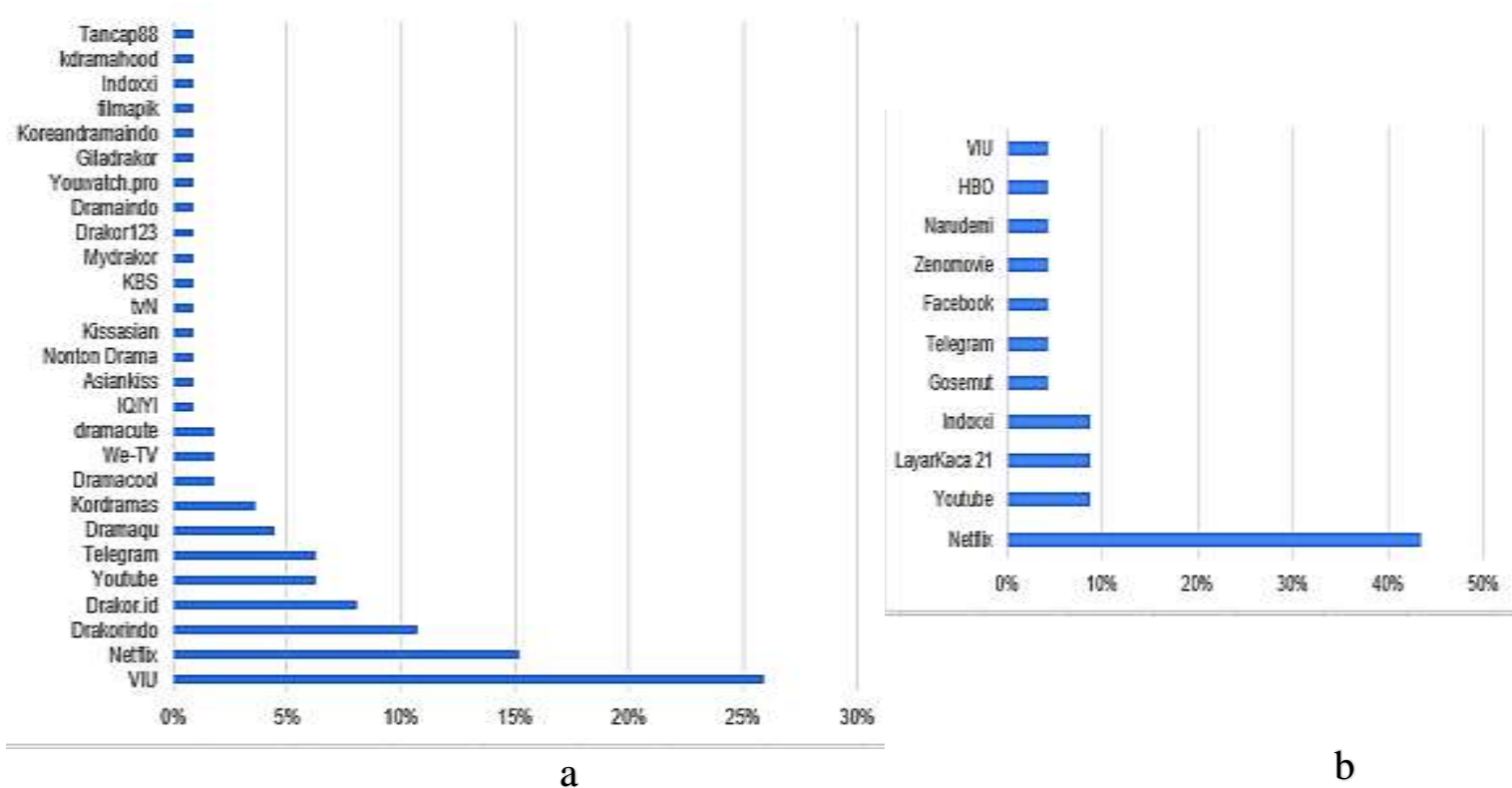

Figure 2. (a) Movie Streaming Media Services for Korean movies/drama; (b) Movie Streaming Media Services for English movies/series 
When it comes to over-the-top (OTT) media services, Korean movie viewers's top choice is Hong Kong-based VIU, which sits at the top with $26 \%$, followed by American-based Netflix tailing at the second place with $11 \%$ difference. This is such a contrast with English movie viewers' preference for streaming services. With this group, Netflix takes the crown with $43 \%$, while VIU falls behind at meager $4 \%$. This is likely because Netflix offers more English movie choices than other conterparts, while VIU provides more varieties for Korean movies and dramas.

Table 1. Korean words taken from drama and recalled by viewers

\begin{tabular}{|c|c|}
\hline Subject & $\begin{array}{l}\text { Korean Input recalled from Korean Drama } \\
(* \text { The spelling for romanized versions were not considered })\end{array}$ \\
\hline 1 & $\begin{array}{l}\text { Neomu mana } \exists \text { Saranghae, choahe, chusuhamnida, } \\
\text { yoboseyo, anyeong, gotjimal, kiyowo, oendung, kabang, pyeonte, } \\
\text { gae seki, yeppo, mashita, bushowo, bukuropta, ramyun, tugowo, } \\
\text { pigonatta, chugule, chinggu, yeoja, pumunim, haraboji, eomma, } \\
\text { appa, oppa, bul, kajog, taeyang, jeongwon, gyeoul, bom, gaeul, } \\
\text { ahjumma, juseyo, gemane, arahseo, nub, ip, kyoron, gae, nappun, } \\
\text { inyeon, haru, byul, sesang, neolpun, naega, oemoni, nokdujeon, soju, } \\
\text { pijamacha, bbap, aigoo, jeongmal, jjinja mianhae, geure, pyeonsang, } \\
\text { uisa, dll }\end{array}$ \\
\hline 2 & $\begin{array}{l}\text { "Aigoo", "Daebak", "Omo", "Aishh", "Jinjja", "Ottokhae", } \\
\text { "Araso", "Yeoboseo", "Bogoshipda", ("hana, dul, set"), } \\
\text { "Saranghae", "Anio", "Andwe", "Chingu", "Chukae", "Yeppeo", } \\
\text { "Wae", "Ya!", "Ttarawa", "Shireo", "Saengilchukae", "Gomawo", ", } \\
\text { "Gamsahabnida", "Sunbae", "Palliwa", "Naega", "Mianhae", } \\
\text { "kyeopta", "Juseo", "Marhaebwa", "Kajja", " Molla", "Micheosseo", } \\
\text { "jebal", " Iga mwoya", "jeongmal", "jigeum", "fighting", "hajiman", } \\
\text { "Eonni", "Eomma", "Ahjussi", " Ajhuma". }\end{array}$ \\
\hline 3 & $\begin{array}{l}\text { 안녕하세요 감사합니다, 고맙습니다, 고마워요 } \\
\text { 여보세요 네 아니야 안돼, 싫어 없이 엄마, 아빠, 할머니, } \\
\text { 할아버지, 아줌마, 아저씨 누나, 형, 오빠, 언니 사장님, 선생님, } \\
\text { 쌤 아가씨, 오라버니, 누이, 왕자, 폐허 생일 축하해 사랑해, } \\
\text { 사랑한다, 사랑하니까 야! 죽을래, 미쳤어 헐 정말, 진짜 어디서 } \\
\text { 왜 그래, 괜찮아 가자 }\end{array}$ \\
\hline 4 & $\begin{array}{l}\text { Annyeong haseyo? Annyeong higaseyo? Uri heeojija? } \\
\text { Arayo Mwo? Ya! Wae? Ne Aniyo Opsoyo Jinja Heol Daebak } \\
\text { Bogoshipoyo Ottokke Chukkae Hana Dul Set Net Daseot Yol seot } \\
\text { Ilgop Yodol Baegopa Mola Saranghae Saranghandago } \\
\text { Ya! Weyo? }\end{array}$ \\
\hline
\end{tabular}

A few samples taken from Korean movie viewers show how many words they could recall while filling out the survey. From the table, we can see that they could retrieve 20-50 words out of their memory. Some of the retrieved Korean words can be catogorized as follow: 1) greetings (ex. 안녕하세요/ Annyeong Haseyo - Hello), 2) Family tree (ex. 엄마/ Eomma - Mom; 아빠/Appa - Dad), 3) Numbers ( ex. 하나/Hana - One; 둘/Dul - Two; 셋/Set -Three), 4) Interjection (ex. 헐/Heol-I can't believe it; 대박/ Daebak - Awesome!) and some others. 
Table 2. English words taken from drama and recalled by viewers

\begin{tabular}{|c|l|}
\hline Subject & \multicolumn{1}{|c|}{ English Input from Film/Series } \\
\hline 5 & \multicolumn{1}{|c|}{ Premonition, Doppelganger, Ditch, Pathetic, Slaughter } \\
\hline 6 & just kidding \\
\hline 7 & $\begin{array}{l}\text { you, Is that so? What do you want? Who are you? How have you } \\
\text { been? }\end{array}$ \\
\hline 8 & $\begin{array}{l}\text { Don't you dare, Approximately, Nobody cares, Take me with } \\
\text { born, treat, inferior }\end{array}$ \\
\hline
\end{tabular}

The number of words recalled by Korean movie viewers is such a jarring contrast with the numbers of words recalled by English movie viewers. From the samples on Table 2, we can see that there are not as many words recalled by English movie viewers as Korean group. Here the words retrieved from the viewers memory are much more varied, as there are : 1) Interjection (ex. Damn! Shit!), 2) Adjectives (ex. pathetic; inferior), 3) common expression (ex. What do you want?; I'm just kidding), and some others.

The striking difference regarding the number of words recalled by both groups might be caused by language exposure they receive prior to movie viewing. For many Indonesian K-drama viewers, their encounter with Korean drama is also their first encounter with the language. Some have got to know Korean words from K-pop songs. Still, many come to view Korean drama with barely any Korean words in their memory, hence it is easier for them to recall what they get from the drama. Meanwhile, English movie viewers have usually learned English formally at school, which mean they watch movies with a number of vocabulary already stored in their mind. It is likely that during the movie viewing, they have already known a number of the words spoken by the characters, resulting in less number in words received from the movie itself.

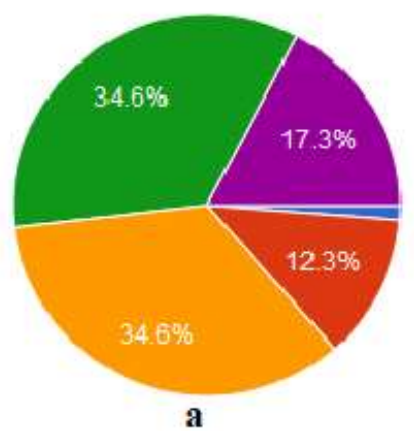

a

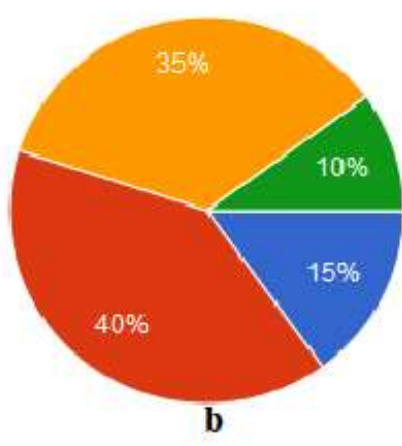

Completely understand

Quite understand

Partly understand

Hardly understand

Can't understand at all

Figure 3. (a) Ability to understand the story without subtitle for Korean movie viewers (b) Ability to understand the story without subtitle for English movie viewers

Figure 3 display viewers' ability in watching the movies without subtitle. Majority of Korean movie viewers rely on subtitles to understand the story, with a tiny portion of the group can completely understand without caption aid. On the contrary, English movie viewers who can understand the movie without subtitle makes over half of the population, while only $45 \%$ of the group need subtitle to 
help them understand the story. This finding confirms the earlier arguments that while Korean movie viewers fill up their vocabulary storage, mostly for the first time, from watching the movies, English movie viewers have already acquired a number of words prior to movie viewing. Hence, English movie viewers can do what Nation calls as "receptive retrieval" (2001) when they retrieve words from their memory during the movie viewing, resulting in less dependency for subtitle. On the other hand, despite being able to mention more words they get from watching Korean movies/drama, the number of words acquired by Korena movie viewers are likely still far less than needed to understand a story without caption aid. Because of that, there are many of them who need subtitle to understand the story.

When being asked what words received from the dramas that they use when communicating, some Korean movie viewers answered as follow:

S1 :Oppa, krn lucu aj ada nadanya (Oppa, because it sounds cute)

S2 :Daebakk, hwaiting, saranghaeyo, mianhae, khamsahamnida. Alasan, karena kata tersebut sudah cukup umum bahkan diantara non fans kdrama ataupun kpop. (Daebak, hwaiting, saranghaeyo, mianhae, khamsahamnida. Because they are common words and even for non fans of kdrama or kpop).

S3 : Jinjja, aigo, gomawo, kwenchana. Karena sering didengar dan simpel. (Jinjja, aigo, gomawo, kwenchana. Because they are common and simple).

S4 : Eonni dan oppa ketika berada di komunitas pencinta kpop.(Eonni and Oppa when I am in Kpop lovers community).

S5 : Aish, jinjja, kkamjagi (bila tanpa sengaja dikeluarkan saat sedang kesal atau kaget) - (Aish, jinjja, kkamjagi - unconsciously use the words when I am upset or shocked).

From their answers, it can be concluded that Korean movie viewers utilize the words they get from the drama to communicate with their community. This indicates that they perform "productive retrieval" (Nation, 2001), as they get to retrieve words from their memory to speak or write.

S6 : Thank you, up to you, dsb. karena artinya mudah dimengerti oleh semиa orang. (Thank you, up to you, dsb. Because people understand them easily).

S7: Tidak ada, karena saya tipe orang yang tidak suka mencampurkan bahasa dalam percakapan sehari-hari (None. Because I am a type who doesn't like to mix languages in daily conversation)

S8 : American English - formal/non-formal. Lebih banyaj formal karena digunakan untuk berkomunikasi dengan rekan kerja orang asing. (American English formal/non formal. Formal is used more often because I need to communicate with foreigner).

Meanwhile, the English movie viewers gave more varied answers and reasons. One said that they use common expression like "Thank you" and "Up to you" because they are generally understood. However, one respondent mentioned of not using any words from movies because he does not like mixing languages. Another repsondent said that she prefers American English since it us used to communicate with foreigners. 


\section{CONCLUSIONS}

Based on the analysis, this study has come with a number of findings. First, Korean movie viewers could recall more words than English movie viewers. Second, Korean movie viewers seem to perform more on the productive retrieval, as they get engaged to conversation with their community and are able to use the words they receive from movies in its spoken or written form when speaking or writing. On the opposite, English movie viewers seem to perform more on the receptive retrieval, which help them to understand the story without needing much help from subtitle. The finding of this study confirms earlier studies' findings (Ashcroft et al., 2018; Peters \& Webb, 2018) that movies can facilite incidental vocabulary acquisition.

\section{REFERENCES}

Ashcroft, R. J., Garner, J., \& Hadingham, O. (2018). Incidental Vocabulary Learning Through Watching Movies. Australian Journal of Applied Linguistics, 1(3), 135-147. https://doi.org/10.29140/ajal.v1n3.89

Carraher, E. (2017). Language and Entertainment: Can Language Be Learned Through Movies ? Linguistics Senior Research Projects., 8, 1-25.

Dzulfahmi, N., \& Nikmah, A. (2019). The Effects of Using Movies in Improving VOcabulary and Motivation to Learn Among Students Across Different Age Groups. Britania Journal of English Teaching, 1(3).

Effendi, M. N. A., Malihah, E., \& Nurbayani, S. (2016). Impact of Korean Drama in Indonesia Through the Spread Moral Values for Young Generation. 1st UPI International Conference on Sociology Education (UPI ICSE), 478-481. https://doi.org/10.2991/icse-15.2016.103

Goctu, R. (2017). Using Movies in EFL Classrooms. European Journal of Language and Literature Studies, 3(2), 121-124.

Ismaili, M. (2013). The Effectiveness of Using Movies in the EFL Classroom - A Study Conducted at South East European University. Academic Journal of Interdisciplinary Studies, 2(4), 121-132. https://doi.org/10.5901/ajis.2012.v2n4p121

Jin, D. Y., \& Yoon, T. J. (2017). The Korean Wave: Retrospect and prospect: Introduction. International Journal of Communication, 11, 2241-2249.

Kabooha, R. H. (2016). Using Movies in EFL Classrooms: A Study Conducted at the English Language Institute (ELI), King Abdul-Aziz University. English Language Teaching, 9(3), 248-257. https://doi.org/10.5539/elt.v9n3p248

King, J. (2002). Using DVD Feature Films in the EFL Classroom. Computer Assisted Language Learning, 21(1), 509-523. https://doi.org/10.1076/call.15.5.509.13468

Krashen, S. D. (1981). Second Language Acquisition and Second Language Learning. Pergamon Press. https://doi.org/10.1111/j.14679922.2009.00554.x

Krashen, S. D. (1985). The Input Hypothesis. Issues and Implications. Longman.

Krashen, S. D. (2004). The Power of Reading : Insights from the Research (2nd Ed). Heinemann.

Krashen, S. D. (2009). Principles and Practice in Second Language Acquisition (Internet E). 
Leeman, J. (2003). Recasts and Second Language Development : Beyond Negative Evidence. Studies in Second Language Acquisition, 25(1), 37-63. https://doi.org/10.1017/S0272263103000020

Mardani, M., \& Najmabadi, A. (2016). The effect of glosses on incidental vocabulary learning of Iranian EFL learners. Esearch in English Language Pedagogy, 4(1), 52-63. https://doi.org/10.7575/aiac.ijalel.v.5n.6p.34

Montero Perez, M., Peters, E., \& Desmet, P. (2018). Vocabulary Learning Through Viewing Video: The Effect of Two Enhancement Techniques. Computer Assisted Language Learning, 31(1-2), 1-26. https://doi.org/10.1080/09588221.2017.1375960

Nation, P. (2001). Learning Vocabulary in Another Language. Cambridge: Cambridge University Press.

Peters, E., \& Webb, S. (2018). Incidental Vocabulary Acquisition Through Viewing L2 Television and Factors that Affect Learning. Studies in Second Language Acquisition, 40(3), 551-577. https://doi.org/10.1017/S0272263117000407

Pigada, M., \& Schmitt, N. (2006). Vocabulary acquisition from extensive reading : A case study. Reading in a Foreign Language, 18(1), 1-28.

Putri, V. K., \& Reese, M. (2018). the Impact of 'Korean Wave' on Young Indonesian Females and Indonesian Culture in Jabodetabek Area. Emerging Markets: Business and Management Studies Journal, 4(1), 35-53. https://doi.org/10.33555/ijembm.v4i1.60

Rahmiati, L. (2012). The Impact of Korean Wave to the Acceptance of Korean Culture and Product among Indonesian. KDI School of Public Policy and Management.

Ramadhani, K., \& Linadi, K. E. (2012). Korean Wave and Potential Impacts on Indonesian Adolescents and Other ASEAN Countries. Journal of Health and Social Behavior, 20-27. https://doi.org/10.1109/TSP.2013.2273886

Robbinson, P., Mackey, A., Gass, S., \& Schmidt, R. (2012). Attention and Awareness in Second Language Acquisition. In S. M. Gass \& A. Mackey (Eds.), The Routledge Handbook of Second Language Acquisition (pp. 247267). New York: Routledge. https://doi.org/10.1002/9781405198431.wbeal0058

Rodrigo, V., Krashen, S., \& Gribbons, B. (2004). The effectiveness of two comprehensible-input approaches to foreign language instruction at the $\begin{array}{llll}\text { intermediate } & \text { level. } & \text { System, } & \text { 53-60. }\end{array}$ https://doi.org/10.1016/j.system.2003.08.003

Saville-Troike, M. (2006). Introducing Second Language Acquisition. New York: Cambridge University Press.

Schmidt, R. (2001). Schmidt, Attention, p. 1. Cognition and Second Language Instruction, 3-32.

Schmidt, R. (2010). Attention , Awareness, and Individual Differences in Language Learning. Proceedings of CLaSIC 2010, 4, 721-737. https://doi.org/10.1515/9781614510932.27

Seferoğlu, G. (2008). Using feature films in language classes. Educational Studies, 34(1), 1-9. https://doi.org/10.1080/03055690701785202

van Zeeland, H., \& Schmitt, N. (2013). Lexical Coverage in L1 and L2 Listening Comprehension: The Same or Different from Reading Comprehension? Applied Linguistics, 34(4), 457-479. https://doi.org/10.1093/applin/ams074 
Vidal, K. (2011). A Comparison of the Effects of Reading and Listening on Incidental Vocabulary Acquisition. Language Learning, 61(1), 219-258. https://doi.org/10.1111/j.1467-9922.2010.00593.x

Ziegler, N. (2018). Task Modality, Noticing, and the Contingency of Recasts. In S. Gass, P. Spinner, \& J. Behney (Eds.), Salience in Second Language Acquisition (pp. 269-290). New York: Routledge. https://doi.org/10.4324/9781315399027-14 